\title{
The Impact of Flexible Working Arrangements on Millennials: A Conceptual Analysis
}

\section{Nur Zafira Akma Rozlan \& Geetha Subramaniam}

To Link this Article: http://dx.doi.org/10.6007/IJARBSS/v10-i11/8152

DOI:10.6007/IJARBSS/v10-i11/8152

Received: 27 September 2020, Revised: 25 October 2020, Accepted: 15 November 2020

Published Online: 27 November 2020

In-Text Citation: (Rozlan, \& Subramaniam, 2020)

To Cite this Article: Rozlan, N. Z. A., \& Subramaniam, G. (2020). The Impact of Flexible Working Arrangements on Millennials - A Conceptual Analysis. International Journal of Academic Research in Business and Social Sciences. 10(11), 938-948.

Copyright: (c) 2020 The Author(s)

Published by Human Resource Management Academic Research Society (www.hrmars.com)

This article is published under the Creative Commons Attribution (CC BY 4.0) license. Anyone may reproduce, distribute, translate and create derivative works of this article (for both commercial and non-commercial purposes), subject to full attribution to the original publication and authors. The full terms of this license may be seen

at: http://creativecommons.org/licences/by/4.0/legalcode

Vol. 10, No. 11, 2020, Pg. 938 - 948

Full Terms \& Conditions of access and use can be found at http://hrmars.com/index.php/pages/detail/publication-ethics 


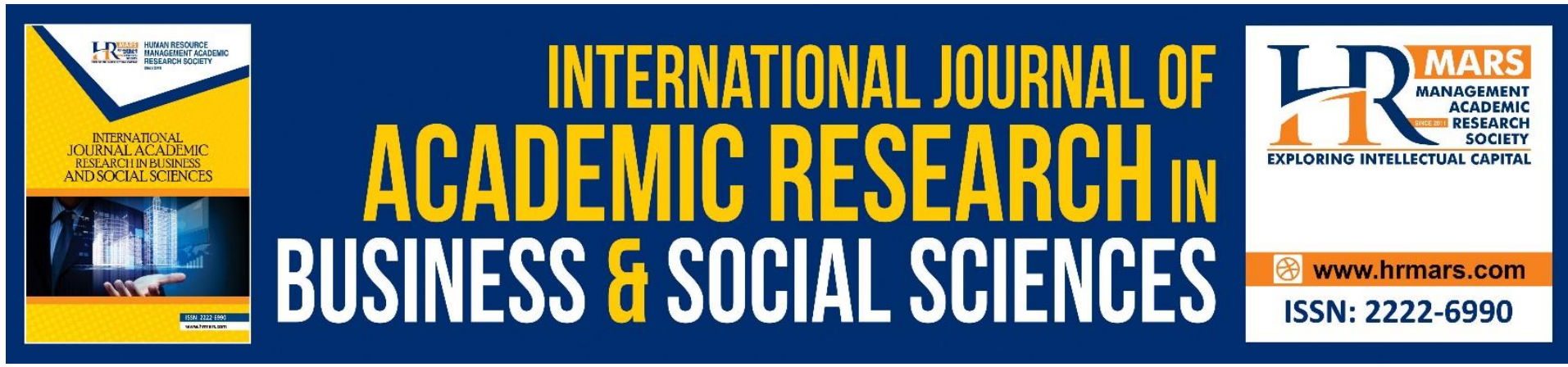

\title{
The Impact of Flexible Working Arrangements on Millennials: A Conceptual Analysis
}

\author{
Nur Zafira Akma Rozlan \& Geetha Subramaniam \\ Faculty of Business and Management, Universiti Teknologi MARA, Selangor \\ Email: gee395@uitm.edu.my
}

\begin{abstract}
Recent statistics show that millennials make up about $40 \%$ of the employees struggling with mental health issues at the workplace in Malaysia. Concurrently, inflexible work schedules have been listed as one of the work place hazards in the National Standard of Canada for Psychological Health and Safety in the workplace. Hence, as millennials will constitute a major part of the global workforce in years to come, it is crucial to study the impact of flexible working arrangements on this category of employees. As flexible working arrangements (FWAs) provide a degree of control to the employees to decide their work arrangements in terms of time, place and method of working, it inadvertently allows an increase in autonomy of the employees. This conceptual paper first deliberates how flexible working arrangements may improve well-being and productivity of millennials since this generation values autonomy more than the previous generations. By using Self-Determination Theory at the workplace, this paper describes how flexible working arrangements (FWAs) support the need for autonomy among millennials, leading to improved well-being and productivity. Arguably, this paper proposes autonomy to be the mediator that links flexible working arrangements (FWAs), well-being and productivity. Finally, a theoretical framework is proposed for future research.
\end{abstract}

Keywords: Flexible Working Arrangements (FWAs), Millennials, Well-Being, Productivity, Autonomy

\section{Introduction}

Flexible working arrangements (FWAs) are types of work arrangements which give a degree of freedom to employees in deciding when, where and how they want to perform work (Subramaniam et al., 2010). Revolving around the strategy of increasing employees' flexibility, FWAs allow for better employees' attunement to both personal needs and organizational goals, which have been linked to better productivity and well-being (Nakrošiene et al., 2019). Initially, FWAs started off as an alternative scheduling, but now they are gradually becoming the new normal as the practice is becoming more common in many developed regions such as United States, United Kingdom, Europe, Australia and New Zealead (Costa et al., 2004). In Asia, although FWAs appear to be less common and are still underimplemented (Azar et al., 2018), its popularity differs across countries. Himawan et al. (2020) 
stated that Hong Kong, Singapore and Japan are among the countries which have been adopting the practice, while others still prefer the traditional, 9-5 work arrangement.

The most common types of FWAs include job sharing, flexitime, working from home (WFH), staggered hours, part-time work, compressed hours and early retirement (TalentCorp, 2018). Despite the discrepancies in the practice of FWAs across countries and regions, the world has witnessed the biggest, unintended experiment of working from home (WFH) arrangement, in support of social distancing policy due to the COVID-19 pandemic. This unprecedented change has forced organizations, especially in Asia, to start considering FWAs as part of the organizational strategy to thrive amidst health and economic crisis, now and in the future (Himawan et al., 2020).

The practice of FWAs is not only beneficial as part of an organizational strategy for crisis management, it is decisively favorable among millennials, who are entering the global workforce, replacing the more conservative baby boomers (Zainuddin et al., 2019). Bernama (2019) reported that by 2025 , the global workforce will be dominated by $75 \%$ millennials.

Millennials, who were born between 1981 and 1996 (Dimock, 2019), carry unique characteristics as compared to the previous generations due to their exposure to world digitalization as they matured. The exposure to the internet and social media while growing up instilled in them the feeling of power and the need to be in charge of making decisions. This generation is no longer holding on to the traditional role as workers, they are acting more like consumers as they have access to unlimited resources in deciding what is best for their performance as employees (Gallup Inc, 2016). While all individuals devour autonomy to some extent, millennials need it more.

Milennials in Malaysia are struggling with poor mental health and decreased wellbeing, which ultimately leads to to the drop of productivity at the workplace. According to Malaysia Well-Being Index released in 2018, the indicator "working life" is ranked the lowest in terms of its contribution towards the general well-being. This is supported by the data released by the National Morbidity and Health Survey (2015), where prevalence of mental health increased 2 -fold across the last two decades. At the workplace, millennials make up about $40 \%$ of the employees struggling with mental health issues. The common mental health problems at work such as depression and anxiety have led towards presenteeism, sickness absenteeism and staff turnover, which are translated into RM 14.46 billion or $1 \%$ of Malaysia GDP in 2018.

WHO has extensively discussed the risk factor that comes with non- flexible working hours and how it can affect the employees (WHO 2019). Inflexible work schedules also have been listed as one of the work place hazards in the National Standard of Canada for Psychological Health and Safety in the workplace (Chua, 2020). However in Malaysia, majority of the organizations that offer FWAs are corporates and this number is relatively small, in comparison with the total number of organizations (TalentCorp, 2018). $91 \%$ of the respondents in a study conducted prefer to have FWAs in the workplace due to the positive perception of flexible working time (Subramaniam et al., 2018).

According to TalentCorp (2018), although FWA option is preferred by $78 \%$ of the millennials, only about $50 \%$ of the organisations offer this workplace policy. Besides, Deloitte Global Millennial Survey (2019) indicated that the percentage of millennials who intend to leave their workplace increased by $20 \%$ by the fifth year of working because the employers did not prioritize FWAs as part of their workplace policy.

With the urgency brought by the COVID-19 pandemic, FWA has again become the subject of interest as the organizations are preparing to move forward with the new normal 
with millennials as the majority of the workforce. Some studies have been done to investigate the link between teleworking and autonomy (ter Hoeven \& van Zoonen, 2015). Despite abundance of literature on FWAs' impact on mental health, well-being and productivity (Costa, 2004) , a theoretical framework that can explain the relationship between FWAs, autonomy, well-being and productivity is largely absent, especially in Asia.

This conceptual paper first gives a theoretical overview of autonomy and its relationship to FWAs and millennials. Using the self-determination theory at the workplace (Deci, et al. 2017), it explains how fulfilment of psychological needs can be used to explain outcomes of job activities. It then further examines two major possible outcomes of FWAs at the workplace, namely well-being and productivity. The paper finally ends with an urgent need for an empirical study to investigate how autonomy may play an important role on millennials' well-being and productivity, if FWAs were provided at the workplace.

\section{Literature Review}

\section{Self-Determination Theory}

Self-determination theory (SDT) (Deci et al., 2017) which has been debated since 1985 attempts to explain the outcomes (ie: well-being and performance) of job activities due to fulfilment of basic psychological needs and different types of motivations. The domains discussed cover parenting, healthcare, sports and physical activity, education, virtual world and psychotherapy. Recently, SDT has been extended to accommodate the domain of work motivation and management. SDT proposes that well-being and productivity of employees at the workplace are influenced by the fulfilment of employees basic psychological needs, namely autonomy, competence and relatedness.

\section{The Need for Autonomy}

Autonomy is defined as having the personal preference in decision making, which results in the perception of being in control of the action course. Experiencing autonomy is pictured as having the freedom to express oneself, without the pressure of external factors (Martela \& Reikki, 2018). Much research has been done on autonomy and its positive outcomes are well established (Fisher, 2010). At the workplace, experiencing autonomy is a luxury among employees, since almost all tasks are clearly defined and pre-decided in accord to the business model or organizational goal.

The practice of FWAs provides a degree of freedom to employees to be in control without compensating the tasks completion expected by the employers. While baby boomers are particularly more comfortable with the idea of being in routine and to abide to certain set of time and place restriction, millennials are different in terms of the value and culture at work (Yap \& Badri, 2020). They are motivated by the agility and flexibility of the workplace, allowing them to become more explorative towards their potential. Autonomy is a crucial priority for millennials as observed from workplace interviews, such that millennials, in general, demand the freedom and flexibility to get the job done in their own way (Aydogmus, 2018). Hee \& Rhung (2019) argues that higher autonomy at the workplace is one of the factors that improve millennials work retention.

SDT proposes that the need for autonomy is a part of basic psychological needs along with competence and relatedness. Despite coming as a package of three, past studies have mainly examined the need for autonomy as a single, representative variable. This is mainly because of two reasons; organizations that provide autonomy are usually attuned to the need 
for competence and relatedness, and employees with a sense of autonomy in finding their way out to fulfill the other two needs (Deci et al., 2017). The fulfillment of autonomy is postulated to be the key towards enhancement of work behavior and increased vitality.

\section{Well-Being}

Well-being is a very broad subject debated for decades, and there is still no absolute definition accepted among scholars. The objective approach defines well-being in terms of quality of life indicators such as material resources (e.g. income, food, housing) and social attributes (education, health, political voice, social networks and connections). The subjective approach emphasizes subjective well-being, that is people's own evaluation of their lives, especially their life satisfaction (a cognitive evaluation), happiness (a positive emotional state) and unhappiness (a negative emotional state) (Western \& Tomaszewski, 2016)

Well-being at the workplace has been a subject of interest among organizational researchers due to the notion of "happy-productive worker" thesis. Fisher (2003) explains that this 'commonsense' theory is based on the assumption that happy employees perform better than their unhappy employees. On the other hand, Tausig (2012) proposes that wellbeing at work is influenced by multiple factors including work-family conflict, job condition, labour market, macro-economic structure and change, and social structures of inequalities. While some of these factors are not equally impactful as they function as a sequence of event, the factor that directly affects well-being at the workplace is job condition, characterized by "demand/ control model"(Karasek, 1979).

Employees who experience high level of demand (tasks) with little control over the task execution is at the higher risk of developing symptoms of distress. Alternatively, employees with better autonomy and control over the work environment is more likely to experience better well-being. This general finding of the positive autonomy-well being relationship holds very true among millennials. This is also in line with Yap \& Badri (2020) who reported that autonomy increases positive effects of millennials, due to the freedom of being able to be creative at the workplace.

\section{Productivity}

Productivity is defined as how inputs (e.g., resources and labour) are used efficiently to produce outputs (e.g. goods and services revenue). In the productivity debate, though equipment and systems are crucial aspects that determine the output of the business, it is undeniable that essentially, business is its people. According to Baard \& Thomas (2010), teleworking is said to improve productivity among the employees in South Africa. Despite the virtual nature of the work, clear instructions and expectations from managers have assisted the employees in achieving better output. This finding is further supported by Gajendran et al. (2015), as teleworking is positively associated with performance through higher autonomy.

On top of that, Hoornweg et al. (2017) argue that high-intensity telecommuting (or working from home) is very crucial for improving productivity. The positive relationship between teleworking and productivity is also explained by the reduced communication with coworkers, suitable workplace at home and the possibilities of taking care of family members at home (Nakrošienè et al., 2019). These factors also have been linked to better performance of the workers (Ongaki, 2019).

Literature has also established that flexible time provides a schedule and/or environment that attunes to personal productivity and leads to improved job performance and productivity (Berkery et al., 2017). Barker (1995), as cited by Berkery et al. (2017) 
emphasises that when employees are given an extent of freedom over when and where to work, employees will choose to work during their most productive hours. On the other hand, Kelliher \& Anderson (2008) emphasize that FWAs would lead to improved quality of work since the task completion is done in an efficient manner comformative to the pace and preference of the employees. On top of that, FWAs also increase the work output as the employees are able to finish extra work (Haddock et al., 2006). Likewise, Gajendran et al. (2015) claim that telecommuting improves the productivity of the work process because it reduces commuting time from and to workplace.

Similarly, the use of new media technologies (e.g., mobile, email) is proposed to promote productive time management and job task coordination (Hurme, 2005). Electronic communication is utilized in a more focused and structured way than face-to-face meetings. In fact, face-to face communication is more time-consuming due to informal conversation that might occur alongside the formal meeting.Communication through e-mail often improves communication efficiency, allowing employees to focus on the message received and to formulate their responses carefully (Warkentin et al., 1997). From an organisational performance viewpoint, employees working in organizations that practice FWAs show significantly stronger association with above-average productivity as compared to employees who work in non-FWAs organizations (Berkery et al., 2017).

Gajendran et al. (2015) found that the positive relationship between telecommuting (a type of FWAs) and productivity is strongly mediated by autonomy. Berkery et al. (2017) found that fulfilled need for autonomy of employees increases job satisfaction and employee motivation. This, in addition, reduces stress and work-home interference and finally leads to increased overall productivity (Berkery et al., 2017).

\section{Proposed Theoretical Framework}

This current study has discussed the literature regarding the relationship between the need for autonomy, well-being and performance. It is well established that the satisfaction of the need for autonomy is largely leading towards increased well-being, as the control over the environment allows employees to become more aware of their personal needs, in addition to the work demands. The positive link between autonomy and productivity is also explained by the opportunity given to employees to explore the best way to complete their task, which is unique by nature.

In the conundrum of SDT, the need for autonomy at the workplace is largely supported by managerial skills. Managerial skills focus on how managers are responsible on creating an autonomy-conducive environment for fellow employees to thrive better and feel better at the workplace. Deci et al. (2017) proposed that there is a need to examine the workplace characteristic, in an attempt to discover more ways to support the need for autonomy among employees. The general idea of FWAs, which centers around the agility and flexibility given to employees to some extent have control over their work time, place and method, and is largely autonomous on its own. Hence, this study proposes FWAs as one of the workplace characteristics that may support the autonomy among employees. The availability of FWAs (even if it is not practiced) gives some sort of freedom, which lead to lesser stressful environment.

Ter Hoeven \& van Zoonan (2015) report that autonomy mediates the relationship between FWAs and well-being. According to Talent Corp (2018), employers mainly provide FWAs as a mean to increase the well-being of employees. About $76 \%$ of the employers reported that the application of work-life practice in terms of FWAs is thought to boost 
employees well-being. The relationship between FWAs and well-being in general (Allen et al., 2013; De Menezes \& Kelliher, 2017; Golden, 2008) in literature has been positively established. Gajendran et al. (2015) found that the positive relationship between telecommuting (a type of FWA) and performance is strongly mediated by autonomy. While Berkery et al. (2017) found that fulfilled need for autonomy of employees increases job satisfaction and employee motivation. This, in addition, reduces stress and work-home interference and finally leads to increased overall productivity (Berkery et al., 2017).

Hence, the paper proposes a theoretical framework, to study the relationship between FWAs, autonomy, subjective well-being and productivity, based on SDT at the workplace.

The keyword is flexibility, which means the power to make decision and to take control over the work is given to millennials, rather than being enforced. The biggest example of FWAs is work from home(WFH) during the pandemic, where the FWAs were enforced rather than given as a choice to the employees. In this extreme case, WFH arrangement might not fulfil the need for autonomy, but in certain cases resulted in more distress, especially due to health and economic crisis (Himawan et al., 2020). On top of that, some employees who were not prepared went through a struggle with the non-ergonomic workspace at home.

This conceptual paper suggests that employers should thrive for a more autonomysupportive work environment for the millennials. In doing so, it is crucial to understand flexibility as the most important element in FWAs that can yield positive outcomes among millennials through the fulfilment of autonomy need.

The implementation of FWAs at the workplace is a beneficial move to both organizations and employees. This is especially true in the case of millennials, who are making up more than $70 \%$ of the global workforce by 2025 , and will soon dictate the diection of the global economy in the next decade.

\section{Conclusion and Future Research Direction}

This conceptual analysis on FWAs and millennials in Malaysia has led to some interesting conclusions. Firstly, this paper develops a theoretical overview of autonomy and its relationship to FWAs and millennials. Secondly, using the self-determination theory, it describes how fulfilment of psychological needs can be used to explain outcomes of job activities. Finally, the paper discusses the urgent need for a future empirical study to investigate how autonomy may play a crucial role on millennials' well-being and productivity, if FWAs were provided by the employers. It can be seen that the implementation of FWAs as part of the workplace policy can benefit both employers and employees. As the world is becoming more digitalized, the practice of FWAs is no longer a choice, but rather a necessity to equip the organizations to thrive in the business.

It is expected that findings from the proposed study would contribute towards a new theoretical knowledge. An extended self-determination theory would be developed in relation to the implementation of flexible working arrangements as a workplace context that provides the need for autonomy. In terms of managerial implications, the findings could further assist the employers to develop a more effective working environment for the new generation entering the workforce. In addition, the study could provide guidelines for organisations which are interested to include the option of FWAs in their workplace policies.

A better understanding of the relationship between autonomy, well-being, and performance will lead to a better interpretation of an effective working arrangement and can help employees to work in a better workplace environment. FWAs can have a significant 
impact on millennials as a whole and also promote a healthy work environment amongst employees in general. To ensure successful implementation of FWAs, organisations are encouraged to enhance their knowledge in the few types of FWAs to identify which works best in their workplaces. Further research is required to fully understand the different mechanisms of various types of FWAs and how they affect employees respectively. An empirical study on millennials in Malaysia working in both FWA organizations and non FWA organization will shed more light on the impact of workplace policies. In line with the third United Nation's Sustainable Development Goal (SDG), which accentuates on well-being of society, it is pertinent that well-being of employee is first given due consideration.

\section{Acknowledgement}

We would like to express our appreciation to the Faculty of Business and Management, Universiti Teknologi MARA, Selangor for the funding of this study.

\section{References}

AIA. (2019). Malaysian Workforce: Sleepless and Overworked? AIA. https://www.aia.com.my/en/about-aia/media-centre/pressreleases/2019/malaysian-workforce-sleepless-and-overworked.html

Aydogmus, C. (2018). Millennials' Career Attitudes: The roles of Career Anchors and Psychological Empowerment. International Journal of Academic Research in Business and Social Sciences, 8(6), 1-21. https://doi.org/10.6007/ijarbss/v8-i6/4176

Allen, T. D., Johnson, R. C., Kiburz, K. M., \& Shockley, K. M. (2013). Work-Family Conflict and Flexible Work Arrangements: Deconstructing Flexibility: PERSONNEL PSYCHOLOGY. Personnel Psychology, 66(2), 345-376. Retrieved from https://doi.org/10.1111/peps.12012

Azar, S., Khan, A., \& Van Eerde, W. (2018). Modelling linkages between flexible work arrangements' use and organizational outcomes. Journal of Business Research, 91, 134-143. Retrieved from https://doi.org/10.1016/j.jbusres.2018.06.004

Baard, N., \& Thomas, A. (2010). Teleworking in South Africa: Employee Benefits and Challenges. Sa Journal of Human Resource Management, 8(1). Retrieved from https://doi.org/10.4102/sajhrm.v8i1.298

Berkery, E., Morley, M. J., Tiernan, S., Purtill, H., \& Parry, E. (2017). On the Uptake of Flexible Working Arrangements and the Association with Human Resource and Organizational Performance Outcomes. European Management Review, 14(2), 165183. Retrieved from https://doi.org/10.1111/emre.12103

Bernama. (2019). Millennials to Dominate Global Workforce by 2025. Retrieved 13 January 2020, from https://www.nst.com.my/news/nation/2019/02/458126/millennialsdominate-global-workforce-2025

Costa, G., Akerstedt, T., Nachreiner, F., Baltieri, F., Carvalhais, J., Folkard, S., ... Silvério, J. (2004). Flexible working hours, health, and well-being in Europe: some considerations from a SALTSA project. Chronobiology International, 21(6), 831-844. Retrieved from https://doi.org/10.1081/cbi-200035935

Chua, S. N. (2020, February). Workplace Mental Health. RELATE Malaysia. Retrieved from https://relate.com.my/wpcontent/ uploads/2020/02/WorkplaceMentalHealth_FA_17022020_BW.pdf

De Menezes, L. M., \& Kelliher, C. (2017). Flexible Working, Individual Performance, and Employee Attitudes: Comparing Formal and Informal Arrangements. Human 
Resource Management, 56(6), 1051-1070. Retrieved from https://doi.org/10.1002/hrm.21822

Deci, E. L., Olafsen, A. H., \& Ryan, R. M. (2017). Self-Determination Theory in Work Organizations: The State of a Science. Annual Review of Organizational Gajendran, R. S., Harrison, D. A., \& Delaney-Klinger, K. (2015). Are Telecommuters Remotely Good Citizens? Unpacking Telecommuting's Effects on Performance Via I-Deals and Job Resources. Personnel Psychology, 68(2), 353-393. Retrieved from https://doi.org/10.1111/peps.12082

Diener, E. (1984). Subjective Well-Being. Retrieved 27 November 2019 from https://papers.ssrn.com/abstract=2162125

Dimock, M. (2019). Defining Generations: Where Millennials End and Generation Z Begins. Retrieved July 22, 2020, from https://www. pewresearch.org/facttank/2019/01/17/where-millennials-end-and-generation-z-begins/

Fisher, C. D. (2003). Why do lay people believe that satisfaction and performance are correlated? possible sources of a commonsense theory. Journal of Organizational Behavior, 24(6), 753-777. https://doi.org/10.1002/job.219

Fisher, C. D. (2010). Happiness at Work. International Journal of Management Reviews, 12(4), 384-412. https://doi.org/10.1111/j.1468-2370.2009.00270.x

Gajendran, R. S., Harrison, D. A., \& Delaney-Klinger, K. (2015). Are Telecommuters Remotely Good Citizens? Unpacking Telecommuting's Effects on Performance Via I-Deals and Job Resources. Personnel Psychology, 68(2), 353-393. Retrieved from https://doi.org/10.1111/peps.12082

Gallup Inc. (2016). How Millennials Want To Work and Live.

Golden, T. D., Veiga, J. F., \& Dino, R. N. (2008). The impact of professional isolation on teleworker job performance and turnover intentions: does time spent teleworking, interacting face-to-face, or having access to communication-enhancing technology matter? The Journal of Applied Psychology, 93(6), 1412-1421. Retrieved from https://doi.org/10.1037/a0012722

Haddock, S. A., Zimmerman, T. S., Lyness, K. P., \& Ziemba, S. J. (2006). Practices of Dual Earner Couples Successfully Balancing Work and Family. Journal of Family and Economic Issues, 27(2), 207-234. https://doi.org/10.1007/s10834-006-9014-y

Hee, O. C., \& Rhung, L. X. (2019). Motivation and Employee Retention among Millennials in Malaysia. International Journal of Academic Research in Business and Social Sciences, 9(2), 876-884. https://doi.org/10.6007/ijarbss/v9-i2/5629

Himawan, K., Fanggidae, J. P., \& Helmi, J.. (2020). The Sociocultural Barriers of Work-FromHome Arrangement Due to COVID-19 Pandemic in Asia: Implications and Future Implementation (Version 1). SageSubmissions. https://doi.org/10.31124/advance.12250190.v1

Hoornweg, N., Peters, P., \& Van der Heijden, B. (2017). Finding the Optimal Mix between Telework and Office Hours to Enhance Employee Productivity: A Study into the Relationship between Telework Intensity and Individual Productivity, with Mediation of Intrinsic Motivation and Moderation of Office Hours. New Ways of Working Practices: Antecedents and Outcomes, 1-28. Retrieved from https://doi.org/10.1108/S1877-636120160000016002

Hurme, P. (2005). Mobile Communication and Work Practices in Knowledge-based Organizations. Human Technology: An Interdisciplinary Journal on Humans in ICT Environments, 1(1), 101-108. https://doi.org/10.17011/ht/urn.2005128 
Karasek, R. A. (1979). Job Demands, Job Decision Latitude, and Mental Strain: Implications for Job Redesign. Administrative Science Quarterly, 24(2), 285. https://doi.org/10.2307/2392498

Kelliher, C., \& Anderson, D. (2008). For better or for worse? An analysis of how flexible working practices influence employees' perceptions of job quality. The International Journal of Human Resource Management, 19(3), 419-431. https://doi.org/10.1080/09585190801895502

Martela, F., \& Riekki, T. J. J. (2018). Autonomy, Competence, Relatedness, and Beneficence: A Multicultural Comparison of the Four Pathways to Meaningful Work. Frontiers in Psychology, 9, 1157.

Ministry of Health Malaysia. (2015). National Health and Morbidity Survey. Author. Retrieved from https://www.moh.gov.my/moh/resources/NHMS2015Volumelll.pdf

Nakrosienè, A., Buciunienè, I., \& Gostautaite, B. (2019). Working from home: characteristics and outcomes of telework. International Journal of Manpower, 40(1), 87-101. Retrieved from https://doi.org/10.1108/IJM-07-2017-0172

Ongaki, J. (2019). An examination of the relationship between flexible work arrangements, work-family conflict, organizational commitment, and job performance. Management-Poland, 23(2), 169-187. Retrieved from https://doi.org/10.2478/manment-2019-0025

Salas-Vallina, A., Alegre, J., \& Fernandez Guerrero, R. (2018). Happiness at work in knowledge-intensive contexts: Opening the research agenda. European Research on Management and Business Economics, 24(3), 149-159. Retrieved from https://doi.org/10.1016/j.iedeen.2018.05.003

Schotanus-Dijkstra, M., Ten Klooster, P. M., Drossaert, C. H. C., Pieterse, M. E., Bolier, L., Walburg, J. A., \& Bohlmeijer, E. T. (2016). Validation of the Flourishing Scale in a sample of people with suboptimal levels of mental well-being. BMC Psychology, 4, 12. Retrieved from https://doi.org/10.1186/s40359-016-0116-5

Subramaniam, G., Ali, E., \& Overton, J. (2010). Are Malaysian women interested in flexible working arrangements at workplace? Business Studies Journal, 2(2), 83-98. Retrieved from

https://www.academia.edu/download/4274235/bsj_vol_2_si_no_2_2010_p_8398.pdf

TalentCorp, E. A. Y. (2018). Life At Work.

Tausig, M. (2012). The Sociology of Work and Well-Being. Handbooks of Sociology and Social Research, 433-455. https://doi.org/10.1007/978-94-007-4276-5_21

Ter Hoeven, C. L., \& Van Zoonen, W. (2015). Flexible Work Designs And Employee WellBeing: Examining The Effects Of Resources And Demands. New Technology, Work And Employment, 30(3), 237-255. Retrieved From Https://Doi.Org/10.1111/ntwe.12052 Psychology and Organizational Behavior, 4(1), 19-43. Retrieved from https://doi.org/10.1146/annurev-orgpsych-032516-113108

Warkentin, M. E., Sayeed, L., \& Hightower, R. (1997). Virtual Teams versus Face-to-Face Teams: An Exploratory Study of a Web-based Conference System. Decision Sciences, 28(4), 975-996. https://doi.org/10.1111/j.1540-5915.1997.tb01338.x

Western, M., \& Tomaszewski, W. (2016). Subjective Wellbeing, Objective Wellbeing and Inequality in Australia. PloS one, 11(10), e0163345.

https://doi.org/10.1371/journal.pone.0163345 
Yap, W. M., \& Zainal Badri, S. K. (2020). What Makes Millennials Happy in their Workplace? Asian Academy of Management Journal, 25(1), 103-121. https://doi.org/10.21315/aamj2020.25.1.6

Zainuddin, Z. N., Latif, N. E. A., Sulaiman, S., Yusof, F. M., \& Ahmad, M. (2019). Critical Thinking: Way Forward for Human Capital in the Age of Millennial. International Journal of Academic Research in Business and Social Sciences, 9(13), 183-195. https://doi.org/10.6007/ijarbss/v9-i13/6254 